\title{
Stall cleanliness and stall temperature of two different freestall bases
}

\author{
B. A. Wadsworth, A. E. Stone, J. D. Clark, D. L. Ray, and J. M. Bewley ${ }^{1}$ \\ Department of Animal and Food Sciences, University of Kentucky, Lexington 40546
}

\begin{abstract}
The objective of this study was to describe the differences in freestall cleanliness and stall temperature between a barn with Dual Chamber Cow Waterbeds (DCCW; Advanced Comfort Technology, Reedsburg, WI) and a barn with rubber-filled mattresses at the University of Kentucky Coldstream Dairy Research Farm from January 18, 2012, to May 3, 2013. Stall cleanliness was measured twice weekly $(\mathrm{n}=134)$ by the same 2 observers using a $0.91 \mathrm{~m} \times 0.91 \mathrm{~m}$ wire grid containing 128 equally sized rectangles (10.16 $\mathrm{cm} \times 5.08 \mathrm{~cm})$. This grid was centered at the rear portion of the stall; a rectangle that was visibly wet or had any amount of feces present was defined as a dirty rectangle. Weekly stall temperature $(\mathrm{n}=66)$ was measured by the same observer during a.m. milkings in the same predetermined stalls. Feces and wet sawdust were removed from the stalls before stall temperatures were acquired. Temperatures were obtained using a handheld thermometer at $30.48 \mathrm{~cm}$ above the stall base as determined via dual laser measurements. Stall temperature was measured on the front, middle, and back of the stall first with clean sawdust and then with the sawdust removed from the stall and wiped clean with a towel. Daily temperature-humidity index (THI) was calculated using Kentucky climate data calculated through the University of Kentucky College of Agriculture via a data logger, located $5.63 \mathrm{~km}$ from the Coldstream Dairy Farm. Stall cleanliness was not different between the DCCW barn $(26.09 \pm 0.89$ rectangles) and the rubber-filled mattress barn (23.70 \pm 0.89 rectangles). Mean THI throughout the study was $64.39 \pm 0.82$. Stall temperature was different among THI categories. Temperature-humidity index categories 1 (coldest), 2, 3, and 4 (warmest) had THI ranges of 22.94 to $50.77,50.77$ to $64.88,64.88$ to 78.75 , and 78.75 to 101.59 , respectively. Stall temperatures $\left({ }^{\circ} \mathrm{C}\right.$; least squares means $\pm \mathrm{SE}$ ) were $2.26 \pm 0.30,8.86 \pm 0.30$, $15.52 \pm 0.30$, and $20.95 \pm 0.30$ for THI categories 1
\end{abstract}

Received October 12, 2014.

Accepted February 25, 2015.

${ }^{1}$ Corresponding author: jbewley@uky.edu to 4 , respectively. Stalls with rubber-filled mattresses had a lower temperature $\left({ }^{\circ} \mathrm{C}\right)$ than $\mathrm{DCCW}$ with least squares means $\pm \mathrm{SE}$ of $10.52 \pm 0.21^{\circ} \mathrm{C}$ and $13.29 \pm$ $0.21^{\circ} \mathrm{C}$, respectively. The $\mathrm{DCCW}$ were probably significantly warmer because water holds heat well. The DCCW may have more of a heat-insulating effect compared with rubber-filled mattresses.

Key words: waterbed, freestall, stall temperature

\section{INTRODUCTION}

Total confinement freestall housing is a common housing choice within the dairy industry (Overton et al., 2003), with $32.6 \%$ of all operations using freestalls to house $60 \%$ of the lactating cattle in the United States (NAHMS, 2007). The primary location where cows come in contact with moisture and manure is the lying environment, making it a major factor affecting cow hygiene (Schreiner and Ruegg, 2003; DeVries et al., 2012). To maintain clean cattle, clean housing is required (Hultgren and Bergsten, 2001; Ruud et al., 2010a). Cow cleanliness is important to guarantee sanitary milking procedures and animal well-being (Ruud et al., 2010b). The stall surface type has a considerable effect on udder hygiene (Schreiner and Ruegg, 2003). Cleaner udders are important because clean udders reduce the risk for mastitis and the need to wash cows' udders in the parlor (Chaplin et al., 2000). Exposure to manure in a housing system can affect the clinical mastitis rate (Schreiner and Ruegg, 2003). Facility management factors may also affect a cow's mastitis rate, such as inadequate bedding or infrequent cleaning of stalls (Schukken et al., 1990).

Weather, mainly temperature and humidity, affects lying times (Endres and Barberg, 2007). Overton et al. (2002) discovered that when environmental temperature increased, lying proportion of eligible cows decreased. Cattle preference for a stall is affected by temperature (Wagner-Storch et al., 2003) as cattle may avoid cold bedding surfaces (Thoreson et al., 2006). The objective of this study was to describe the differences of freestall cleanliness and stall temperature between a barn with Dual Chamber Cow Waterbeds (DCCW; Advanced Comfort Technology, Reedsburg, WI) and a barn with rubber-filled mattresses (MAT). 


\section{MATERIALS AND METHODS}

This study was conducted in 2 freestall barns at the University of Kentucky Coldstream Dairy Research Farm (Lexington, KY) from January 18, 2012, to May 3,2013 . In each barn, the brisket locator was a $7.62 \mathrm{~cm}$ schedule 40 polyvinyl chloride pipe. Stall length from brisket locator to curb side of the alley was $1.8 \mathrm{~m}$. Neck rail height from bottom of the rail to top of the stall base was $1.2 \mathrm{~m}$. Mean stall width was $1.2 \mathrm{~m}$. Each freestall barn consisted of 6 rows with 9 freestalls in each row (Figure 1). The DCCW freestall barn included 54 stalls with DCCW as the stall base, and the MAT freestall barn included 54 stalls with MAT as the stall base. Access to 4 stalls in each freestall barn was restricted because their width was too narrow for cows, leaving cows with access to 50 stalls in each freestall barn. Each DCCW was filled with $49.2 \mathrm{~L}$ of water, with the ability for water to flow between 2 chambers (front and back). The MAT was filled with equally sized rubber crumbs. The MAT cells were then covered with a CS wax-coated single top covering for every row of stalls. Eight 48-inch 6-blade box fans (Schaefer, Sauk Rapids, $\mathrm{MN}$ ) and four 36-inch 3-blade round fans (Schaefer) hung above the stalls in both freestall barns and were manually controlled by farm staff. Cows were milked 2 times at 0430 and $1530 \mathrm{~h}$. Stalls were manually raked clean once before barns were cleaned in the a.m. with a skid steer bucket and scrape tire. Kiln-dried sawdust $(8.02 \pm 0.11 \mathrm{~kg} /$ stall $)$ was applied to each stall every other day with a skid steer bucket. Care was taken by farm staff to ensure the same amount of sawdust was applied to stalls in each barn.

\section{Measurements}

Sawdust measurements $(\mathrm{n}=35)$ were determined every $2 \mathrm{wk}$ in predetermined stalls with a premeasured weigh tub after stalls had been bedded (Figure 1). The premeasured weigh tub was determined before the start of the study; weights were recorded on the side of the tub with premeasured weights of sawdust. The predetermined stalls were selected randomly with the same positions represented in each barn. Three stalls were chosen in each row, and 2 stalls represented each column of stalls the length of the barn (Figure 1).

Stall cleanliness (SC) was measured twice weekly ( $\mathrm{n}=134)$ by the same 2 observers using a $0.91 \mathrm{~m} \times$ $0.91 \mathrm{~m}$ wire grid containing 128 equally sized rectangles $(10.16 \mathrm{~cm} \times 5.08 \mathrm{~cm})$. The grid was centered at the rear portion of the stall, so that the bottom of the grid was flush with the curbside of the alley. Rectangles that were visibly wet or had any amount of feces present were defined as dirty rectangles. The total number of dirty rectangles was calculated for each predetermined stall before performing stall maintenance.

Weekly stall temperature $(\mathbf{S T} ; \mathrm{n}=66)$ was measured by the same observer during a.m. milkings in the same predetermined stalls as was described for SC. Stall temperature measurements started 30 min after the cows were moved to the holding pen, and feces and wet sawdust were scraped off to allow acclimation to ambient temperatures. Temperatures were obtained using a handheld Dual Laser InfraRed Thermometer (Extech Instruments, Nashua, NH) at $30.48 \mathrm{~cm}$ above the stall base as determined via dual laser measurements. To get a whole stall temperature representative, the front, middle, and back of the stalls temperature was measured first with clean sawdust on the stall and then without sawdust on the stall that was scraped clean and then wiped with a towel.

Daily temperature-humidity index (THI) was calculated using daily weather through Kentucky climate data. The climate data were calculated through the University of Kentucky College of Agriculture, Food, and Environment via a Campbell Scientific Inc. (Logan, UT) $23 \times$ data logger, located $5.63 \mathrm{~km}$ from the Coldstream Dairy Farm. Temperature-humidity index was computed using the following formula (NOAA, 1976): $\mathrm{THI}=$ temperature $\left({ }^{\circ} \mathrm{F}\right)-[0.55-(0.55 \times$ relative humidity $/ 100)] \times\left[\right.$ temperature $\left.\left({ }^{\circ} \mathrm{F}\right)-58.8\right]$. This study used maximum daily temperature and maximum relative humidity to calculate THI.

\section{Statistical Analysis}

The UNIVARIATE procedure of SAS (version 9.3, SAS Institute Inc., Cary, NC) was used to calculate the 1st and 99th percentiles of SC score, which were then removed from the data set to remove any outliers. The MEANS procedure of SAS was used to generate the mean SC over the course of the study for each stall. The variable tested was freestall barn. The GLM procedure of SAS was used to evaluate SC.

The UNIVARIATE procedure of SAS (SAS Institute Inc.) was used to calculate the 1st and 99th percentiles of sawdust weight, which were then removed from the data set to remove any outliers. The mean sawdust weight was determined per freestall barn and stall number using the MEANS procedure of SAS. Variables tested were stall number and freestall barn. The GLM procedure of SAS was used to evaluate sawdust weight. The 2-way interaction was tested and stepwise backward elimination was used to remove nonsignificant interactions $(P \geq 0.05)$. All main effects were kept in the model regardless of significance level. 


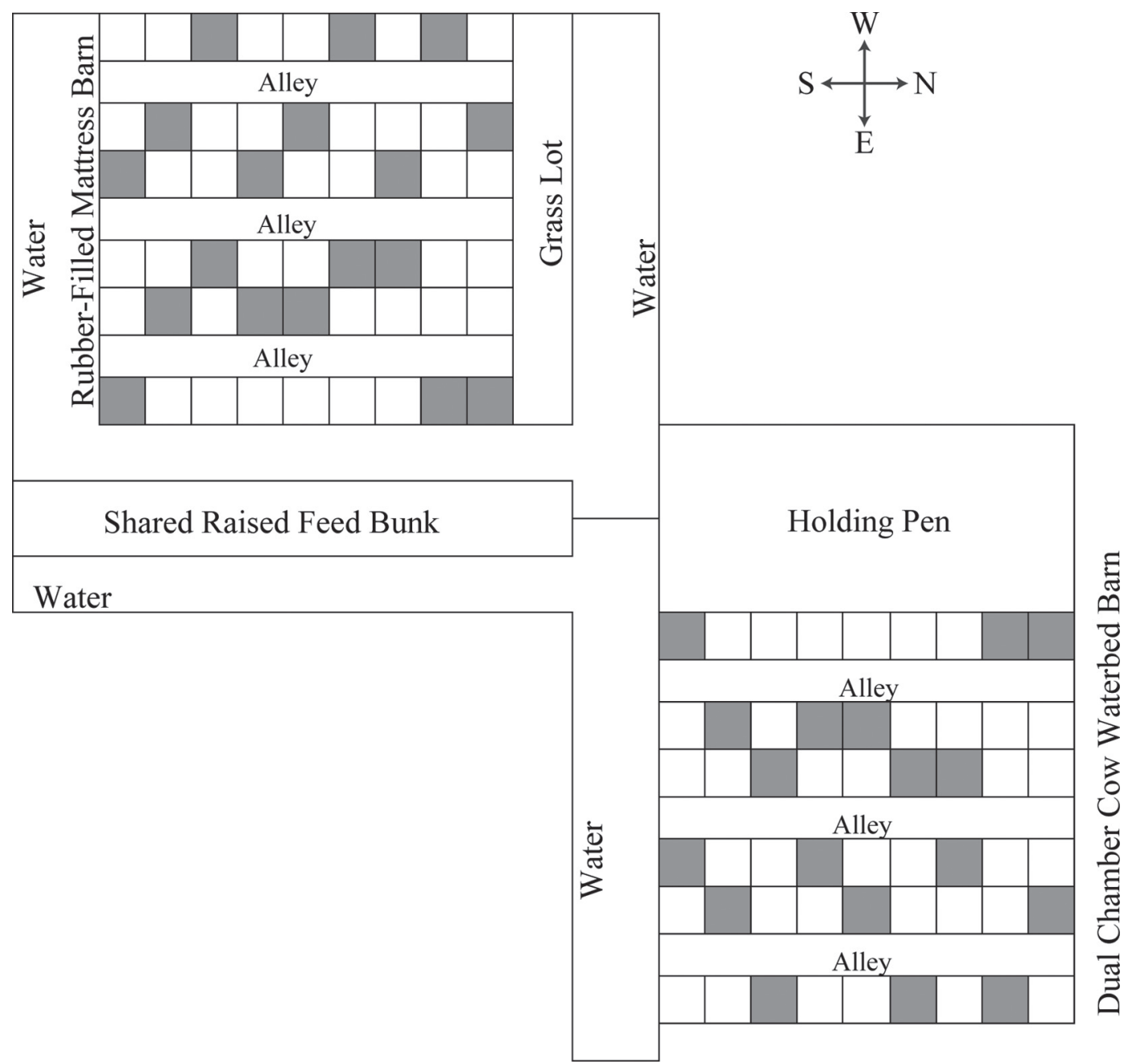

Figure 1. Layout of freestall barns with Dual Chamber Cow Waterbeds and rubber-filled mattress freestall bases; shaded boxes represent stalls that were measured for cleanliness, temperature, and sawdust weight.

Temperature-humidity index was split into quartile categories using the UNIVARIATE procedure of SAS. Temperature-humidity index quartile categories 1 (coldest), 2, 3, and 4 (warmest) had THI ranges of 22.94 to $50.77,50.77$ to $64.88,64.88$ to 78.75 , and 78.75 to 101.59 , respectively. Stall temperature means were calculated before and after sawdust was removed across the whole study using the MEANS procedure of SAS. Means for the front, middle, and back of the stall were calculated before and after the sawdust was removed to determine each whole stall average. Variables tested were THI and freestall barn. The GLM procedure of SAS was used to evaluate ST. The 2-way interaction was tested and stepwise backward elimination was used to remove nonsignificant interactions $(P \geq 0.05)$. All main effects were kept in the model regardless of significance level.

\section{RESULTS AND DISCUSSION}

\section{Stall Cleanliness}

Stall cleanliness was not different $(P \geq 0.05)$ between the DCCW barn (26.09 \pm 0.89 rectangles) and the MAT barn (23.70 \pm 0.89 rectangles). Sawdust weights were not different $(P \geq 0.05)$ between stalls in the DCCW barn $(8.45 \pm 0.45 \mathrm{~kg})$ and the MAT barn $(7.54$ $\pm 0.45 \mathrm{~kg})$. Both barns had the same cleaning schedule, the same amount of sawdust applied, and stocking density never exceeded $100 \%$. Therefore, this result is not surprising.

The total area of each stall was $85.04 \mathrm{~m}^{2}$. The DCCW and MAT barns on average had total dirtiness areas of 7.95 and $7.22 \mathrm{~m}^{2}$, respectively. Both Jerseys and crossbreds were housed in both barns. These smaller 
cows may have made the stalls dirty, as stalls that are being used may become dirty as cows urinate, defecate, and track manure into them. When the neck rail was furthest away from the curb in a study performed by Tucker et al. (2005), the cows stood with all 4 hooves in the stall. In a similar study, when the neck rail was positioned furthest from the curb, cows stood with all 4 hooves in the stall and more manure came in contact with the stall than when the neck rail was positioned closer (Fregonesi et al., 2009). When the neck rail was absent, manure was more likely to contact the stall than when the neck rail was present (Tucker et al., 2005). Smaller cows may be able to stand with all 4 hooves in the stall regardless of neck rail absence or presence, dirtying the stalls.

\section{Stall Temperature}

Mean THI throughout the study was $64.39 \pm 0.82$. Stall temperature was different $(P<0.01)$ among THI categories (Table 1). Stall temperatures $\left({ }^{\circ} \mathrm{C}\right.$; least squares means $\pm \mathrm{SE}$ ) were $2.26 \pm 0.30,8.86 \pm 0.30$, $15.52 \pm 0.30$, and $20.95 \pm 0.30$ for THI categories 1 to 4, respectively. As THI increased, ST also increased. This result is likely because multilayered stall surfaces have a heat-insulating capacity (Nilsson, 1988).

Stall temperature was different $(P<0.01)$ between freestall barns (Table 2). The DCCW least squares means ST was $13.29 \pm 0.21^{\circ} \mathrm{C}$ and the MAT least squares means ST was $10.52 \pm 0.21^{\circ} \mathrm{C}$. These results are likely because water has the ability to hold and conserve heat. If stall temperatures are too cold or too warm, they could have an effect on cattle preference for stall use (Fulwider and Palmer, 2004). No study, that

Table 1. Least squares means \pm SE daily stall temperature for each temperature-humidity index (THI) category 1 (coldest) to 4 (warmest) ${ }^{1}$

\begin{tabular}{lcc}
\hline $\begin{array}{l}\text { THI } \\
\text { category }\end{array}$ & THI range & Stall temperature ${ }^{2}\left({ }^{\circ} \mathrm{C}\right)$ \\
\hline 1 & 22.94 to 50.77 & $2.26 \pm 0.30^{\mathrm{a}}$ \\
2 & 50.77 to 64.88 & $8.86 \pm 0.30^{\mathrm{b}}$ \\
3 & 64.88 to 78.75 & $15.52 \pm 0.30^{\mathrm{c}}$ \\
4 & 78.75 to 101.59 & $20.95 \pm 0.30^{\mathrm{d}}$ \\
\hline
\end{tabular}

${ }^{\mathrm{a}-\mathrm{d}}$ Pairs with different superscript letters are significantly different $(P$ $\leq 0.05)$.

${ }^{1}$ Stalls were in 2 separate freestall barns with Dual Chamber Cow Waterbeds (Advanced Comfort Technology, Reedsburg, WI) as a freestall base in one barn and rubber-filled mattresses as a freestall base in the other barn. Temperature-humidity index was calculated from daily weather reports and was split into categories using the UNIVARIATE procedure in SAS (version 9.3, SAS Institute Inc., Cary, NC).

${ }^{2}$ Stall temperatures were calculated using a handheld Dual Laser InfraRed Thermometer (Extech Instruments, Nashua, NH) in 3 stalls in each row in each barn. Weekly temperatures were averaged across the whole study period.
Table 2. Least squares means \pm SE weekly stall temperature for a barn with rubber-filled mattresses as a freestall base compared with a barn with Dual Chamber Cow Waterbeds (Advanced Comfort Technology, Reedsburg, WI) as a freestall base ${ }^{1}$

\begin{tabular}{lc}
\hline Barn & $\begin{array}{c}\text { Weekly stall temperature } \\
\left({ }^{\circ} \mathrm{C}\right)\end{array}$ \\
\hline Rubber-filled mattress & $10.52 \pm 0.21^{\mathrm{a}}$ \\
Dual Chamber Cow Waterbed & $13.29 \pm 0.21^{\mathrm{b}}$ \\
\hline${ }^{\mathrm{a}, \mathrm{b}}$ Pairs with different superscript letters are different $(P \leq 0.05)$. \\
${ }^{1}$ Stall temperatures were calculated using a handheld Dual Laser \\
InfraRed Thermometer (Extech Instruments, Nashua, NH) in 3 stalls \\
in each row in each barn. Weekly temperatures were averaged across \\
the whole study period.
\end{tabular}

the authors are aware of, has investigated the mean stall temperature between DCCW and MAT. One study did investigate the temperature difference between granite fines and sand. Temperature for stalls bedded with granite fines was less than stalls bedded with sand ( $\mathrm{Pa}-$ nivivat et al., 2005). An infrared thermometer was used to show the temperature differences between granite fines and sand, displaying that infrared thermometers are useful to show stall surface differences.

During the coldest months of a Wisconsin study comparing 13 different stall bases, waterbeds were the most preferred stall base for resting. Comparing stall occupancy across the whole study, waterbeds had the highest occupancy at all temperature ranges. During the coldest times of the year, waterbeds may be the preferred stall base due to their ability to hold and conserve heat (Fulwider and Palmer, 2004). Although stall occupancy was not observed in the current study, in a different study in the same freestall barns, conducted at the same time, researchers evaluated cow lying times between barns. Researchers discovered significantly different lying times of 10:32 $\pm 13.2 \mathrm{~min}$ and 9:47 \pm 15 min for the DCCW barn and the MAT barn, respectively [B. A. Wadsworth, A. E. Stone, C. L. Wood (University of Kentucky), K. J McQuerry (University of Kentucky), J. D. Clark, D. L. Ray, J. M. Bewley, unpublished data). Water temperatures in DCCW can fluctuate depending on cow occupancy. When a cow lies down on a waterbed, conductive heat loss from the cow increases the water temperature inside the bed (Bastian et al., 2003). The DCCW barn cows had higher lying times, which could explain why the DCCW temperatures were higher.

\section{CONCLUSIONS}

Stall cleanliness was not different between the DCCW freestall barn and the MAT freestall barn. Although cow cleanliness and milk quality were not evaluated in this study, future research projects may focus on all of 
these aspects combined. Stall temperatures increased as THI increased. Both freestall barn stall bases held heat well, but stall temperatures were significantly greater in the DCCW barn compared with the MAT barn. Dual Chamber Cow Waterbeds may have more of a heatinsulating effect compared with MAT. These factors should be considered when determining the usefulness of stall bases on farms.

\section{ACKNOWLEDGMENTS}

The authors send their sincerest thank you to Advanced Comfort Technologies Inc. (Reedsburg, WI) for the donation of the Dual Chamber Cow Waterbeds and the financial support needed to complete this study. We thank Donna Amaral-Phillips, Maegan Weatherly and Karmella Dolecheck for their help in editing. We thank Taylor Reiter, Yu Zang, Carly Becker, Alexis Thompson, Candace Thompson, Anna Rogers, and Jake Richardson (University of Kentucky) for their help with the project. We also thank Greg Rutledge, Chris French, Hugo Hamilton, and the rest of the Coldstream Dairy Farm staff for their continuous dedication to the project.

\section{REFERENCES}

Bastian, K. R., K. G. Gebremedhin, and N. R. Scott. 2003. A finite difference model to determine conduction heat Loss to a waterfilled mattress for dairy cows. ASAE 46:773.

Chaplin, S. J., G. Tierney, C. Stockwell, D. N. Logue, and M. Kelly. 2000. An evaluation of mattresses and mats in two dairy units. Appl. Anim. Behav. Sci. 66:263-272.

DeVries, T. J., M. G. Aarnoudse, H. W. Barkema, K. E. Leslie, and M. A. G. von Keyserlingk. 2012. Associations of dairy cow behavior, barn hygiene, cow hygiene, and risk of elevated somatic cell count. J. Dairy Sci. 95:5730-5739.

Endres, M. I., and A. E. Barberg. 2007. Behavior of dairy cows in an alternative bedded-pack housing system. J. Dairy Sci. 90:41924200.

Fregonesi, J. A., M. A. G. von Keyserlingk, C. B. Tucker, D. M. Veira, and D. M. Weary. 2009. Neck-rail position in the free stall affects standing behavior and udder and stall cleanliness. J. Dairy Sci. 92:1979-1985.
Fulwider, W. K., and R. W. Palmer. 2004. Stall usage differences of thirteen different freestall base types. Prof. Anim. Sci. 20:470482.

Hultgren, J., and C. Bergsten. 2001. Effects of a rubber-slatted flooring system on cleanliness and foot health in tied dairy cows. Prev. Vet. Med. 52:75-89.

NAHMS (National Animal Health Monitoring System). 2007. Facility characteristics an cow comfort on U.S. dairy operations. USDA:APHIS:VS, Center for Epidemiology and Animal Health, National Animal Health Monitoring Systems, Fort Collins, CO.

Nilsson, C. 1988. Floors in animal houses: Technical design with respect to the biological needs of animals in reference to the thermal, friction and abrasive characteristics and the softness of the flooring material. Sveriges Lantbruksuniversitet, Lund, Sweden.

NOAA. 1976. Livestock hot weather stress. Pages C31-76 in Proc. US Dept. Commerce, Natl. Weather Serv. Central Reg. Operations Manual Lett. Natl. Oceanic Atmospheric Admin., Kansas City, MO.

Overton, M. W., D. A. Moore, and W. M. Sischo. 2003. Comparison of commonly used indices to evaluate dairy cattle lying behavior. Pages 125-130 in Proc. Fifth Int. Dairy Housing Conference, Fort Worth, TX. ASAE, St. Joseph, MI.

Overton, M. W., W. M. Sischo, G. D. Temple, and D. A. Moore. 2002 Using time-lapse video photography to assess dairy cattle lying behavior in a free-stall barn. J. Dairy Sci. 85:2407-2413.

Panivivat, R., E. B. Kegley, D. W. Kellogg, J. A. Pennington, K. Vandevender, D. H. Hellwig, T. J. Wistuba, and S. L. Krumpelman. 2005. Preference of dairy cows for free-stalls bedded with sand or granite fines and changes in bacterial counts in those materials. Prof. Anim. Sci. 21:248-253.

Ruud, L. E., K. E. Bøe, and O. Østerås. 2010a. Associations of soft flooring materials in free stalls with milk yield, clinical mastitis, teat lesions, and removal of dairy cows. J. Dairy Sci. 93:15781586.

Ruud, L. E., K. E. Bøe, and O. Østerås. 2010b. Risk factors for dirty dairy cows in Norwegian freestall systems. J. Dairy Sci. 93:52165224 .

Schreiner, D. A., and P. L. Ruegg. 2003. Relationship between udder and leg hygiene scores and subclinical mastitis. J. Dairy Sci. 86:3460-3465.

Schukken, Y. H., F. J. Grommers, D. Van De Geer, H. N. Erb, and A. Brand. 1990. Risk factors for clinical mastitis in herds with a low bulk milk somatic cell count. 1. Data and risk factors for all cases. J. Dairy Sci. 73:3463-3471.

Thoreson, D.. L. Timms, and D. Lay. 2006. Dairy free stall preference field study. Iowa State University Annual Industry Report R2100. Iowa State University, Ames.

Tucker, C. B., D. M. Weary, and D. Fraser. 2005. Influence of neck-rail placement on free-stall preference, use, and cleanliness. J. Dairy Sci. 88:2730-2737.

Wagner-Storch, A. M., R. W. Palmer, and D. W. Kammel. 2003. Factors affecting stall use for different freestall bases. J. Dairy Sci. $86: 2253-2266$. 